\title{
КВАНТОВО-ХИМИЧЕСКОЕ МОДЕЛИРОВАНИЕ АНТИРАДИКАЛЬНОЙ АКТИВНОСТИ НОВОГО ЗАМЕЩЕННОГО АРИЛКАРБАМАТА В ОТНОШЕНИИ СУПЕРОКСИД АНИОН-РАДИКАЛА
}

\author{
М.Н. Коляда', К.П. Пащенко², Ю.Д. Минина \\ ${ }^{1}$ Южный научный центр РАН, 344006, Россия, Ростов-на-Дону, ул. Чехова, 14. \\ 2ФГБОУ ВО «Астраханский государственный технический университет», \\ 414056, Россия, Астрахань, ул. Татищева, 16.
}

DOI: 10.19163/MedChemRussia2021-2021-485

E-mail:mnkolyada@mail.ru

Известно, что функционально замещенные арил- и гетарилкарбаматы перспективны в качестве потенциальных пролекарств с широким спектром фармакологической активности [1]. В данной работе проведено квантово-химическое моделирование антирадикальной активности нового замещенного арилкарбамата (1) (рис. 1), в сравнении с ионолом (2) - известным фенольным антиоксидантом, в отношении супероксид анион-радикала $\left(\mathrm{O}_{2}{ }^{\cdot-}\right)$ - исходной реактивной формы кислорода в живом организме.<smiles>C/C(=N/NC(N)=O)c1c(O)[nH]c(=O)sc1=O</smiles>

1<smiles>Cc1cc(C(C)(C)C)c(O)c(C(C)(C)C)c1</smiles>

2

Рис. 1. Структура исследуемых фенольных соединений

Антирадикальную активность исследуемых соединений в отношении $\mathrm{O}_{2}{ }^{-}$ оценивали, моделируя их взаимодействие с данной реактивной формой кислорода по схеме: $\mathrm{ROH}+\mathrm{O}_{2}{ }^{-}=\mathrm{RO}^{*}+\mathrm{HO}_{2}^{-}$

Расчет энергетических эффектов ( $\Delta \mathrm{E})$ реакций, проведенный методом функционала плотности с использованием программы Gaussian 09, показал, что значение $\Delta \mathrm{E}$ для реакции соединения $1 \mathrm{c} \mathrm{O}_{2}{ }^{-}$составляет 108,8 кДж/моль, для реакции ионола с О: ${ }^{-2}-68,5$ кДж/моль. Таким образом, в рамках используемого модельного подхода новый замещенный арилкарбамат уступает ионолу по способности к «нейтрализации» $\mathrm{O}_{2}{ }^{--}$.

Работа выполнена при поддержке гранта РФФИ 19-03-00006.

\section{Литература}

[1] K.T. Hansen, P. Faarup, and H. Bundgaard, J. Pharm. Sci. 1991, 80, 793-798. 